\title{
PUZZLING RADIOCARBON DATES FOR THE UPPER PALEOLITHIC SITE OF SUNGIR (CENTRAL RUSSIAN PLAIN)
}

\author{
Yaroslav V Kuzmin ${ }^{1}$ Johannes van der Plicht ${ }^{2} \cdot$ Leopold D Sulerzhitsky ${ }^{3}$ \\ ABSTRACT. A summary is presented of more than a decade-long study of direct radiocarbon dating for one of the most \\ important human burials in Eurasia, the Sungir site in eastern Europe. Eighteen ${ }^{14} \mathrm{C}$ dates were produced before early 2014 \\ on three skeletons (Sungir 1-3), and there is still no consistency in the results. In the absence of other independent methods \\ to establish the antiquity of Sungir, a careful analysis is performed of the site's stratigraphy, paleoenvironment, and ${ }^{14} \mathrm{C}$ dates \\ run on animal bones from the same layer as the burials. Although the conclusions of this work cannot be guaranteed to be \\ absolutely correct, we suggest that at the present stage of research the age range of $\sim 26,000-27,210 \mathrm{BP}$ is the most probable \\ time for the creation of the elaborate human burials at the Sungir site.
}

\section{INTRODUCTION}

The Sungir (aka Sunghir and Sungir') site in central Russia $\left(56^{\circ} 11^{\prime} \mathrm{N}, 40^{\circ} 30^{\prime} \mathrm{E}\right.$; see Figure 1) contains unique human burials (e.g. Bahder 1967; Bahn 2001:428-9). Archaeologically, the site belongs to the middle stage of the Upper Paleolithic. Since the 1990s, several campaigns have been carried out in order to establish the age of the Sungir human remains by direct accelerator mass spectrometry (AMS) radiocarbon dating of bone collagen (Pettitt and Bader 2000; Kuzmin et al. 2004; Dobrovolskaya et al. 2012; Marom et al. 2012). However, distinct discrepancies were recognized after the first two studies (Pettitt and Bader 2000 vs. Kuzmin et al. 2004), and their cause remained unclear (see Kuzmin et al. 2004:733). This article reports new direct AMS ${ }^{14} \mathrm{C}$ dates on Sungir human burials. This study critically analyzes the entire corpus of information, including the stratigraphy and other ${ }^{14} \mathrm{C}$ dates from Sungir, in an attempt to understand the puzzling situation when ${ }^{14} \mathrm{C}$ dates produced on the same skeleton in different laboratories are several thousand years apart.

\section{MATERIAL AND METHODS}

The best-preserved human burials from the Sungir complex (which includes both a burial ground and an occupation site; see NO Bader 1998) are Sungir 1, 2, and 3 (S-1, S-2, and S-3, respectively). They were the subject of intensive archaeological, anthropological, and isotope analyses (e.g. NO Bader 1998; Alekseeva and Bader 2000). The first direct AMS ${ }^{14} \mathrm{C}$ dates were published by Pettitt and Bader (2000), followed by Kuzmin et al. (2004), and more recently by Marom et al. (2012) and Dobrovolskaya et al. (2012). Other ${ }^{14} \mathrm{C}$ dates were produced on animal bones (Sulerzhitsky et al. 2000) and charcoal from the cultural layer of Sungir. It should be noted that some of the first ${ }^{14} \mathrm{C}$ values from Sungir, 24,430 $\pm 400 \mathrm{BP}(\mathrm{GrN}-5446)$ on reindeer bones, and 25,500 $\pm 200 \mathrm{BP}(\mathrm{GrN}-$ 5425 ) on charcoal, were run in the late 1960s at the University of Groningen (Vogel and Waterbolk 1972:65).

Several techniques of collagen extraction and purification were applied to the human bones from Sungir by various laboratories: dissolution in cold $\mathrm{HCl}$ (University of Arizona, lab code AA); improved Longin (1971) method (University of Groningen, lab code GrA); gelatinization (some of the University of Oxford dates, lab code OxA); ultrafiltration (some of the OxA values; and dates from Kiel

1. Institute of Geology and Mineralogy, Siberian Branch of the Russian Academy of Sciences, Novosibirsk 630090, Russia. Corresponding author. E-mail: kuzmin@fulbrightmail.org.

2. Center for Isotope Research, University of Groningen, Groningen, the Netherlands; and Faculty of Archaeology, Leiden University, Leiden, the Netherlands.

3. Geological Institute, Russian Academy of Sciences, Moscow 199034, Russia (deceased).

Proceedings of the Radiocarbon and Archaeology 7th International Symposium

Ghent, Belgium, April 2013 | Edited by Mark Van Strydonck, Philippe Crombé, and Guy De Mulder

(C) 2014 by the Arizona Board of Regents on behalf of the University of Arizona 


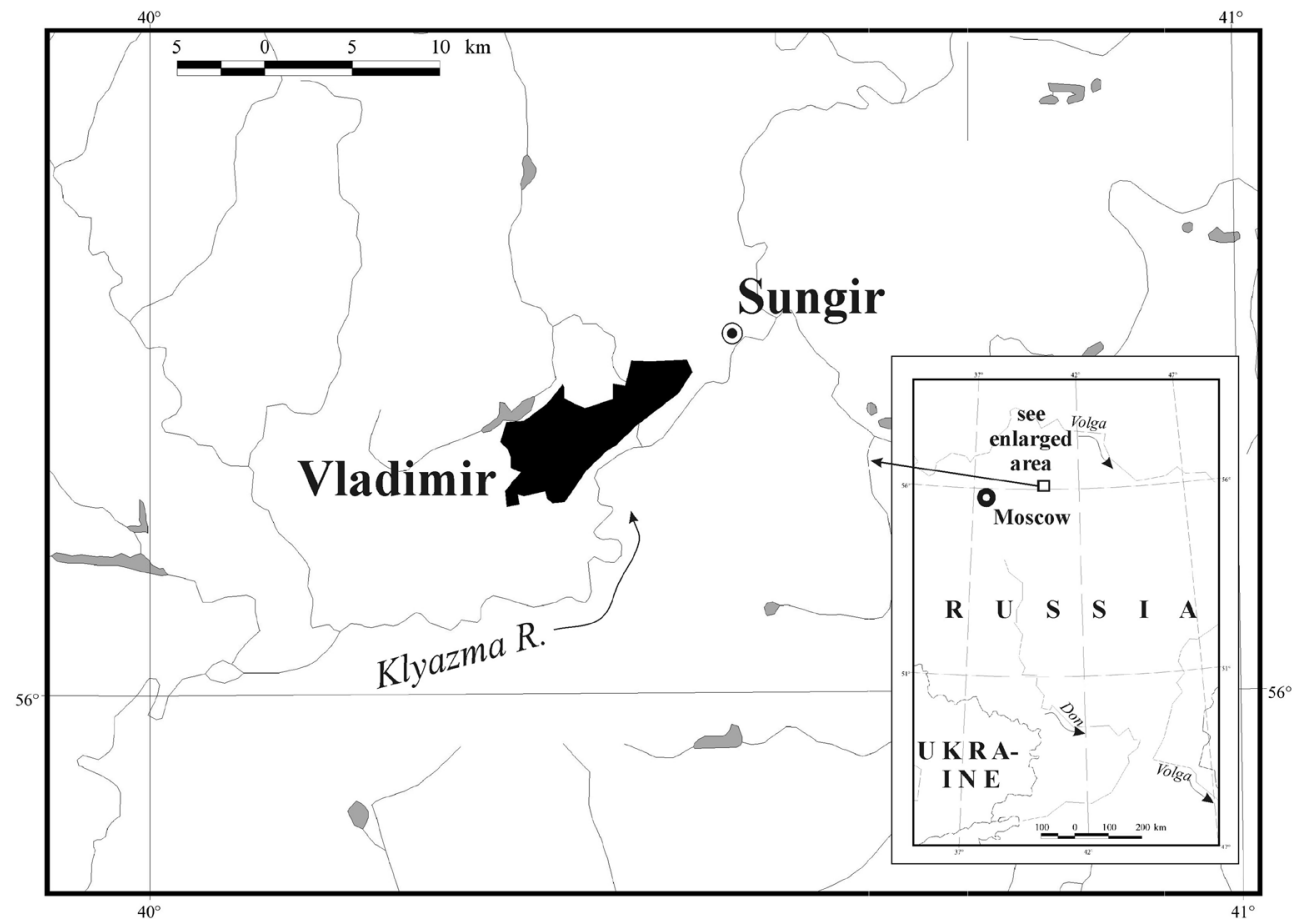

Figure 1 Location of the Sungir site on the Russian Plain

University, lab code KIA); and specific compound extraction (hydroxyproline; Oxford-produced, lab code OxX). Details about the dating techniques can be found in the relevant publications (Zenin et al. 2000; Kuzmin et al. 2004; Brock et al. 2010; Dobrovolskaya et al. 2012; Marom et al. 2012).

Dobrovolskaya et al. (2012:99) mentioned that for the collagen used in the Arizona series “... pretreatment, however, did not include any gelatinization or filtration steps." Although no filtration was done, gelatinization was performed as is clearly indicated (see Kuzmin et al. 2004:732). Earlier, Sulerzhitsky (1997:185-6) described his technique of collagen extraction, and reported the collagen dissolution in weak acidic water at $100^{\circ} \mathrm{C}$, i.e. the gelatinization process. Thus, the Arizona samples were pretreated using the current methodological level; therefore, they are considered reliable.

After recognizing the obvious discrepancies between the data generated by Pettitt and Bader (2000) and Kuzmin et al. (2004), we were able to obtain additional samples from the Sungir burials, which supposedly were not treated with preservatives, although we do not have documentation that could confirm this. Three samples were ${ }^{14} \mathrm{C}$ dated at the University of Groningen in 2004-2007. A fragment of vertebra belonging to the S-1 skeleton accidentally was broken into two pieces, and it was decided to date them separately. For the S-1 and S-2 skeletons, collagen was extracted using the improved Longin method (e.g. Zenin et al. 2000:746). One sample of carbonized collagen from the S-3 skeleton (5 mg weight), originally measured at the Arizona laboratory (Kuzmin et al. 2004), was remeasured.

Data on the ${ }^{14} \mathrm{C}$ dates on charcoal and animal bones from the Sungir complex (Sulerzhitsky et al. 2000), and the site's stratigraphy and paleoenvironment (NO Bader 1998; Alekseeva and Bader 2000), was also taken into account. Unfortunately, this information is not well known outside of Russia; only recently some of it was published in English (Dobrovolskaya et al. 2012). 


\section{RESULTS AND DISCUSSION}

All the direct AMS ${ }^{14} \mathrm{C}$ values for the Sungir humans published to date (early 2014) are summarized in Table 1. The new Groningen dates are as follows: for the S-1 grave, two subsamples of a vertebra fragment gave very different results of $\sim 26,300 \mathrm{BP}$ (GrA-21507) and 21,310 BP (GrA-21513). The double grave with skeletons S-2 and S-3 was dated to 24,170 BP (S-3) and 26,190 BP (S-2). The Groningen samples show good quality parameters (see Table 2) in terms of the carbon content of the collagen (37.2-40.4\%) and the $\delta^{13} \mathrm{C}$ values (e.g. Mook and Streurman 1983). The $\delta^{15} \mathrm{~N}$ and C:N values for the GrA-34760 specimen are also good, and the C:N ratio is within the acceptable range ( 2.9-3.6; e.g. DeNiro 1985).

The reason for the large difference between the two subsamples of S-1 is unclear. It is noticeable that the younger value (GrA-21513) has a very low collagen yield, less than $0.1 \%$ (Table 2 ), which makes it insecure (e.g. Brock et al. 2012). Examples of very diverse collagen yields for the same individual are known: for example, the Kennewick skeleton (e.g. Taylor and Southon 2012:985). Another possible explanation is the uneven contamination by conservant matter. Therefore, the GrA-21513 value can be discarded as unreliable. The GrA-28182 value obtained on the same sample as AA-36476 is perhaps slightly younger than it should be, and should also be excluded.

A critical evaluation of the Sungir series of AMS ${ }^{14} \mathrm{C}$ dates is necessary in an attempt to understand their age. In order to do this, the following circumstances should be taken into account: (1) the stratigraphic situation (e.g. ON Bader 1998), which shows that both burials and items from the occupation zone of Sungir (artifacts and animal bones) belong to the cultural stratum $\sim 80 \mathrm{~cm}$ thick (see Figure 2), and the ages of the burials and the occupation site should to a large extent be contemporaneous; (2) the Sungir site existed before the Last Glacial Maximum ( 16,000-22,000 BP, or $\sim 19,000-26,000$ cal BP; see Clark et al. 2009) because the S-1 burial is disturbed by an ice wedge (see Figure 2), and the site was partly destroyed by solifluction; and (3) the S-2 and S-3 skeletons from the double grave should have identical ${ }^{14} \mathrm{C}$ dates.

There are $22{ }^{14} \mathrm{C}$ dates from the cultural layer of the Sungir site run on animal bones obtained from the excavations between 1958 and 1995; for most of them, the exact provenance is known (Sulerzhitsky et al. 2000:30). These bones were usually not treated with any preservatives. The ${ }^{14} \mathrm{C}$ values range between $\sim 20,360$ and $\sim 28,800 \mathrm{BP}$, and 19 dates are in the range $\sim 26,300-28,800 \mathrm{BP}$ (see also Dobrovolskaya et al. 2012:98). Dates from the lower part of the Sungir cultural layer (horizons 3-4) are 27,200 BP (GIN-9586) and 27,460 BP (OxA-9039). Bones were collected from controlled excavations (Sulerzhitsky et al. 2000:32), and can serve as the lower limit of the Sungir chronology. The calendar age range for these bones is $\sim 30,880-32,790$ cal BP (Figure 3).

There are also nine older ${ }^{14} \mathrm{C}$ values $(\sim 27,630-28,800 \mathrm{BP})$ run on mammoth bones, but they may well reflect scavenging of subfossil bone material, which was widely practiced in the Upper Paleolithic of the Russian Plain (e.g. Soffer 1993; Praslov and Soulerjytsky 1997; Praslov and Sulerzhitsky 1999). In this case, bones of smaller animals representing a common prey of the hunter-gatherers are closely related to the time of the site's existence; five values run on horse and reindeer bones are $\sim 25,700-27,400$ BP (Sulerzhitsky et al. 2000).

Marom et al. (2012:6880) stated that they obtained a sample of mammoth bone "that came from the same occupation area of the site" as the burials. This, however, is incorrect. The new OxX-2395-8 date $(30,100 \pm 400 \mathrm{BP})$ is run on the same piece of mammoth bone as the previous OxA-9039 date (see Marom et al. 2012). In a primary source, it is indicated that the bone was collected in 1995 from Excavation Pit III, grid S/157 (Sulerzhitsky et al. 2000). Pettitt and Bader (2000:207) described it 


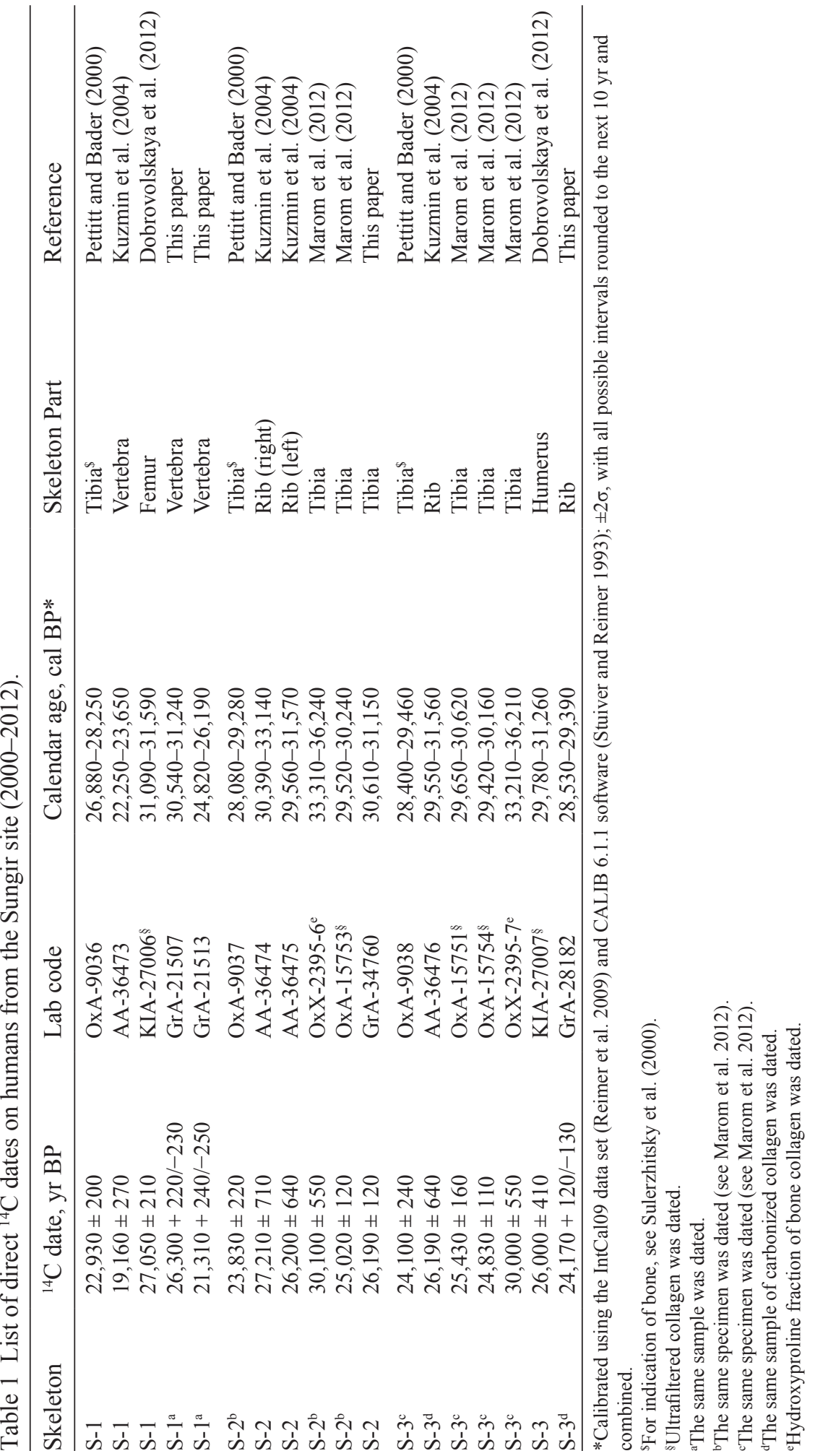


Table 2 Characteristics of collagen of the Sungir 1-3 burials (after Pettitt and Bader 2000; Richards et al. 2001; Kuzmin et al. 2004; Marom et al. 2012; Dobrovolskaya et al. 2012; see Table 1). A long dash means that information does not exist or is not available.

\begin{tabular}{llllll}
\hline Skeleton & ${ }^{14} \mathrm{C}$ date & $\delta^{13} \mathrm{C}, \% 0$ & $\delta^{15} \mathrm{~N}, \% 0$ & C:N ratio & Collagen yield, \% \\
\hline S-1 & OxA-9036 & -19.2 & 11.3 & - & - \\
& AA-36473 & $-20.0^{\mathrm{a}}$ & - & - & - \\
& KIA-27006 & -19.5 & 10.7 & 3.1 & - \\
& GrA-21507 & -19.8 & - & - & 0.6 \\
S-2 & GrA-21513 & -19.2 & - & - & $<0.1$ \\
& OxA-9037 & -19.0 & 11.2 & 3.5 & $6.0^{\mathrm{b}}$ \\
& AA-36474 & $-19.3^{\mathrm{a}}$ & - & - & - \\
& AA-36475 & $-19.7^{\mathrm{a}}$ & - & - & - \\
& OxX-2395-6 & - & - & $5.0^{\mathrm{c}}$ & $9.5^{\mathrm{b}}$ \\
& OxA-15753 & - & - & 3.3 & $9.5^{\mathrm{b}}$ \\
$\mathrm{S}$ S-3 & GrA-34760 & -19.9 & 11.1 & 3.1 & 5.4 \\
& OxA-9038 & -18.9 & 11.3 & 3.4 & $6.1^{\mathrm{b}}$ \\
& AA-36476 & $-19.7^{\mathrm{a}}$ & - & - & - \\
& OxA-15751 & - & - & 3.2 & $3.4^{\mathrm{b}}$ \\
& OxA-15754 & - & - & 3.2 & $3.4^{\mathrm{b}}$ \\
& OxX-2395-7 & - & - & $5.1^{\mathrm{c}}$ & - \\
& KIA-27007 & -19.6 & 11.0 & 3.5 & - \\
\hline
\end{tabular}

${ }^{a}$ The $\delta^{13} \mathrm{C}$ values of carbonized collagen (see Kuzmin et al. 2004) were measured.

bIt is not clearly stated that these values belong to the OxA-9037 and OxA-9038 samples, but we assume that these are specimens processed with the "gelatinization method" while others are "ultrafiltered" samples (Marom et al. 2012, Supporting Information, Table S2; see also Marom et al. 2012:6879).

'These are normal values for hydroxyproline fraction (see Marom et al. 2012:6879).

${ }^{\mathrm{d}}$ This is sample of carbonized collagen, which is why the collagen yield is unknown.

as the "main cultural accumulation at the site," which means the occupation area within the cultural layer and not the burial ground. On the general excavation plans (ON Bader 1998:8; Bader and Mikhailova 1998:168), the 1995 pit where the mammoth bone was collected is situated about 65 $\mathrm{m}$ away from the burials. That is why the identical age of the mammoth bone and the S-2 and S-3 skeletons (see Marom et al. 2012) is not a convincing argument in favor of the superior reliability of the hydroxyproline-based ${ }^{14} \mathrm{C}$ dates compared to other age determinations of the Sungir humans.

The majority of the Sungir faunal remains belong to reindeer (Alekseeva 1998). It seems that the site was situated near a ford where animals crossed the river (paleo-Klyazma), and human occupation might have continued for several millennia (although with frequent interruptions) as the wide range of ${ }^{14} \mathrm{C}$ dates from the site demonstrates (Sulerzhitsky et al. 2000; Sulerzhitsky 2004). Bones of reindeer at Sungir are ${ }^{14} \mathrm{C}$ dated to $\sim 26,900-27,360$ BP (Sulerzhitsky et al. 2000; see also Dobrovolskaya et al. 2012 where they are indicated as "deer").

The charcoal dated to $\sim 21,800-22,500 \mathrm{BP}$, and supposedly collected from below the human bones, was previously associated with the S-1 skeleton (Sulerzhitsky et al. 2000; Kuzmin et al. 2004; Dobrovolskaya et al. 2012). The controversy between these ${ }^{14} \mathrm{C}$ dates and the majority of direct ${ }^{14} \mathrm{C}$ ages for S-1 requires an analysis. Careful study of earlier sources has shown the following: ON Bader (1998:32-43) indicated that the S-1 burial was found in August 1964, and in the same year 
SE

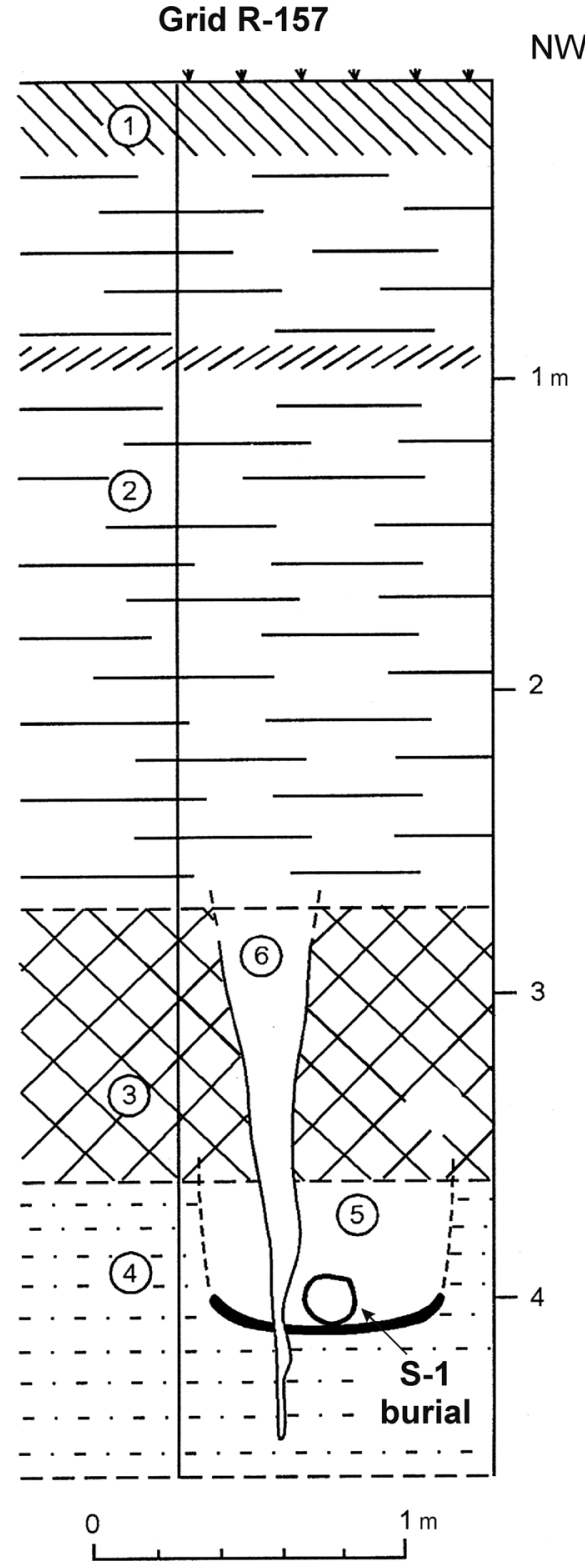

NW
Figure 2 Stratigraphy of the Sungir 1 burial (after ON Bader 1998, with additions): 1 - modern soil; 2 - colluvial loam with paleosol (at a depth of $\sim 1$ m below surface); 3 - Bryansk paleosol containing the cultural layer, with both occupation zone and graves, and with solifluction structures; 4 - sandy loam below burial; 5 - grave pit infill; 6 - ice wedge.

it was taken to Moscow for final cleaning and conservation. Random small pieces of charcoal were detected at the bottom of the grave pit below the S-1 skeleton; some larger charcoal fragments were found above the bottom in direct association with human bones (ON Bader 1998:40).

However, ${ }^{14} \mathrm{C}$ dating of these pieces was not conducted. In the original report (Cherdyntsev et al. 1969:184), it is clearly stated that charcoal was collected in 1967 only from the hearth in the cultural layer by NV Kind (date of 21,800 $\pm 1000 \mathrm{BP}$; GIN-326a) and by ON Bader (date of 22,500 $\pm 600 \mathrm{BP}$; GIN-326b) (see also Bader 1978:64). Therefore, it would have been impossible to obtain the charcoal from the S-1 burial in 1967 because it had been completely excavated in 1964. This made 


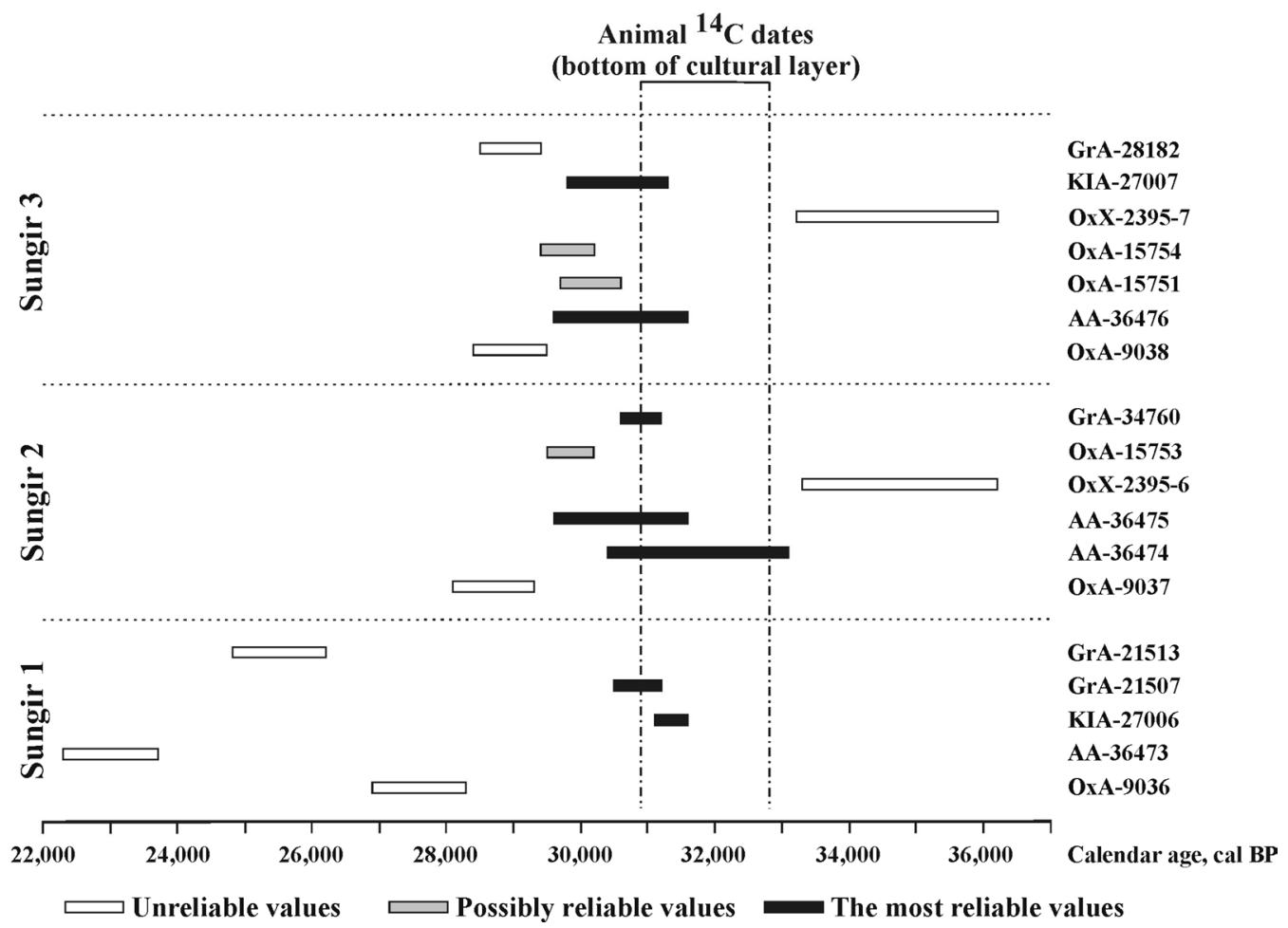

Figure 3 Calendar ages of the Sungir skeletons (see Table 1)

it feasible to reject the association between these charcoal ${ }^{14} \mathrm{C}$ values from the cultural layer and the S-1 burial. From now on, they should be removed from the corpus of ${ }^{14} \mathrm{C}$ dates related to the Sungir burials. Based on this conclusion, the AA-36473 and OxA-9036 dates for the S-1 skeleton $(\sim 19,160-22,930$ BP) appear to be too young (Figure 3).

The issue of contamination for the Sungir human bones was recently raised by Marom et al. (2012). During the excavations in the 1960s, bones were treated with a butyral solution in ethanol for conservation (ON Bader 1998:13-8). Marom et al. (2012, Supporting Information, p 2) also mention "polymer comprising tree sap (termed kanefol), polyvinylbutyral, and phenol/formaldehyde, mixed together with ethanol" as a conservant matter. These compounds might be responsible for the discrepancies observed in the series of ${ }^{14} \mathrm{C}$ dates (e.g. Marom et al. 2012). However, butyral and other similar chemicals were usually produced in the former USSR from a ${ }^{14} \mathrm{C}$-free fossil raw material (Paleozoic-Mesozoic oil), and it is less likely that some "young" ${ }^{14} \mathrm{C}$ was introduced during the conservation process; nevertheless, such a possibility remains.

Based on the evidence presented, the KIA-27006 and GrA-21507 values are the most reliable age estimates of the S-1 burial: 26,300-27,050 BP. Their calibrated ages are $\sim 30,540-31,590$ cal BP, overlapping at $\pm 2 \sigma$ (Table 1 ). Concerning the S-2 skeleton, the GrA-34760 value is the closest to the S-1 values, corresponding to $\sim 30,610-31,150$ cal BP (Figure 3). The AA-36474 and AA-36475 values are close to it, although due to the larger standard deviations their calendar ages are wider, $\sim 29,560-33,140$ cal BP (Table 1). Among the S-3 dates, the AA-36476 and KIA-27007 values are the closest to the S-2 ages (Figure 3); their calendar range is $\sim 29,550-31,560$ cal BP. The narrowest possible interval for all 3 skeletons from Sungir could be $\sim 30,540-31,590 \mathrm{cal}$ BP. This is in good agreement with other ${ }^{14} \mathrm{C}$ records, and the stratigraphic data. 
The statement by Marom et al. (2012:6880), "In the case of Sungir and Kostenki the direct radiocarbon dates previously obtained are erroneous and should henceforth be set out to one side by prehistorians," in our opinion is an exaggeration. As has been demonstrated above, the hydroxyproline-based ${ }^{14} \mathrm{C}$ dates of $\sim 30,000-30,100 \mathrm{BP}$ for Sungir (Marom et al. 2012) contradict the available evidence on the chronology of this site complex (see Figure 3).

\section{CONCLUSIONS}

The true age of the Sungir humans is still unknown. This is partly due to a situation where researchers lack chronological markers like the Campanian Ignimbrite at the Kostenki cluster (e.g. Sinitsyn and Hoffecker 2006) to cross-check the age of a site independently. Based on analysis of the existing ${ }^{14} \mathrm{C}$ and other records, the most probable age range for the S-1 to S-3 skeletons is $\sim 26,000$ $27,210 \mathrm{BP}$ (calendar ages as narrow as $\sim 30,540-31,590 \mathrm{cal} \mathrm{BP}$, and as wide as $\sim 29,780-33,140 \mathrm{cal}$ BP). Without a new chronometric study of the Sungir skeletons, including collagen quality control at the modern level of research and chemical identification of possible contaminants, it will be impossible to solve this puzzle.

\section{ACKNOWLEDGMENTS}

We are grateful to Dr Maria M Pevzner (Geological Institute, Russian Academy of Sciences, Moscow) for providing information for some of the Sungir samples. We acknowledge Prof Nikolai O Bader (Institute of Archaeology, Russian Academy of Sciences, Moscow) for important comments on stratigraphy of the Sungir site. Dr Susan G Keates (Düsseldorf, Germany) kindly checked the grammar of the earlier version of this paper and gave some useful suggestions, and we are thankful for that. Finally, we are grateful to two anonymous reviewers for their comments.

\section{REFERENCES}

Alekseeva LI. 1998. Okhotnichya fauna stoyanki Sungir [The prey fauna of the Sungir site]. In: Bader NO, editor. Pozdnepaleoliticheskoe Poselenie Sungir (Pogrebeniya i Prirodnaya Sreda). Moscow: Nauchny Mir Publishers. p 240-57. In Russian.

Alekseeva TI, Bader NO, editors. 2000. Homo sungirensis. Upper Palaeolithic Man: Ecological and Evolutionary Aspects of the Investigation. Moscow: Nauchny Mir Publishers. 468 p. In Russian with English abstract.

Bader NO, editor. 1998. Pozdnepaleoliticheskoe Poselenie Sungir (Pogrebeniya i Prirodnaya Sreda). Moscow: Nauchny Mir Publishers. 270 p. In Russian.

Bader NO, Mikhailova LA. 1998. Kulturny sloi poseleniya Sungir po raskopkam 1987-1995 godov [The cultural layer of the Sungir settlement according to the 1987-1995 excavations]. In: Bader NO, editor. Pozdnepaleoliticheskoe Poselenie Sungir (Pogrebeniya $i$ Prirodnaya Sreda). Moscow: Nauchny Mir Publishers. p 165-88. In Russian.

Bader ON. 1978. Sungir. Verkhnepaleoliticheskaya Stoyanka [Sungir. An Upper Paleolithic Site]. Moscow: Nauka Publishers. 271 p. In Russian.

Bader ON. 1998. Sungir. Paleoliticheskie porgebeniya [The Sungir site. Paleolithic burials]. In: Bader NO, editor. Pozdnepaleoliticheskoe Poselenie Sungir (Pogrebeniya $i$ Prirodnaya Sreda). Moscow: Nauchny Mir Publishers. p 5-158. In Russian.

Bahder ON. 1967. Eine ungewöhnliche paläolitische
Bestattung in Mittelrußland. Quartär 18:191-4.

Bahn P, editor. 2001. The Penguin Archaeology Guide. London: Penguin Books. 494 p.

Brock F, Higham T, Ditchfield P, Bronk Ramsey C. 2010. Current pretreatment methods for AMS radiocarbon dating at the Oxford Radiocarbon Accelerator Unit (ORAU). Radiocarbon 52(1):103-12.

Brock F, Wood R, Higham TFG, Ditchfield P, Bayliss A, Bronk Ramsey C. 2012. Reliability of nitrogen content $(\% \mathrm{~N})$ and carbon:nitrogen atomic ratios $(\mathrm{C}: \mathrm{N})$ as indicators of collagen preservation suitable for radiocarbon dating. Radiocarbon 54(34):879-86.

Cherdyntsev VV, Zavelsky FS, Kind NV, Sulerzhitsky LD, Forova VS. 1969. Radiouglerodnye daty GIN AN SSSR. Soobshchenie IV [Radiocarbon dates of the Geological Institute, USSR Academy of Sciences. Report IV]. Bulleten Komissii po Izucheniyu Chetvertichnogo Perioda 36:172-93. In Russian.

Clark PU, Dyke AS, Shakun JD, Carlson AE, Clark J, Wohlfarth B, Mitrovica JX, Hostetler SW, McCabe AM. 2009. The Last Glacial Maximum. Science 325(5941):710-4.

DeNiro M. 1985. Postmortem preservation and alteration of in vivo bone collagen isotope ratios in relation to palaeodietary reconstruction. Nature 317(6040):806-9.

Dobrovolskaya M, Richards MP, Trinkaus E. 2012. Direct radiocarbon dates for the mid Upper Paleolithic 
(eastern Gravettian) burials from Sunghir, Russia. Bulletins et Mémoires de la Société d'Anthropologie de Paris 24:96-102.

Kuzmin YV, Burr GS, Jull AJT, Sulerzhitsky LD. 2004. AMS ${ }^{14} \mathrm{C}$ age of the Upper Palaeolithic skeletons from Sungir site, Central Russian Plain. Nuclear Instruments and Methods in Physics Research B 223-224:731-4.

Longin R. 1971. New method of collagen extraction for radiocarbon dating. Nature 230(5291):241-2.

Marom A, McCullagh JSO, Higham TFG, Sinitsyn AA, Hedges REM. 2012. Single amino acid radiocarbon dating of Upper Paleolithic modern humans. Proceedings of the National Academy of Sciences of the USA 109(18):6878-81.

Mook WG, Streurman HJ. 1983. Physical and chemical aspects of radiocarbon dating. In: Mook WG, Waterbolk HT, editors. Proceedings of the First International Symposium ${ }^{14} \mathrm{C}$ and Archaeology, Groningen, 1981. Strasbourg: Council of Europe. p 31-55.

Pettitt PB, Bader NO. 2000. Direct AMS radiocarbon dates for the Sungir mid Upper Palaeolithic burials. Antiquity 74(284):269-70.

Praslov ND, Soulerjytsky LD. 1997. De nouvelles données chronologiques pour le Paléolithique de Kostienki-sur-Don. Préhistoire Européenne 11:133-43.

Praslov ND, Sulerzhitsky LD. 1999. New data on the chronology of Paleolithic sites in Kostenki-on-Don. Doklady Earth Sciences 365(2):196-200.

Reimer PJ, Baillie MGL, Bard E, Bayliss A, Beck JW, Blackwell PG, Bronk Ramsey C, Buck CE, Burr GS, Edwards RL, Friedrich M, Grootes PM, Guilderson TP, Hajdas I, Heaton TJ, Hogg AG, Hughen KA, Kaiser KF, Kromer B, McCormac FG, Manning SW, Reimer RW, Richards DA, Southon JR, Talamo S, Turney CSM, van der Plicht J, Weyhenmeyer CE. 2009. IntCa109 and Marine09 radiocarbon age calibration curves, $0-50,000$ years cal BP. Radiocarbon 51(4):1111-50.

Richards MP, Pettitt PB, Stiner MC, Trinkaus E. 2001. Stable isotope evidence for increasing dietary breadth in the European mid-Upper Paleolithic. Proceedings of the National Academy of Sciences of the USA 98(11):6528-32.

Sinitsyn AA, Hoffecker JF. 2006. Radiocarbon dating and chronology of the Early Upper Paleolithic at Kostenki. Quaternary International 152-153:17585.

Soffer O. 1993. Upper Palaeolithic adaptations in
Central and Eastern Europe and man-mammoth interactions. In: Soffer O, Praslov ND, editors. From Kostenki to Clovis: Upper Palaeolithic - Paleo-Indian Adaptations. New York: Plenum Press. p 31-49.

Stuiver M, Reimer PJ. 1993. Extended ${ }^{14} \mathrm{C}$ data base and revised CALIB $3.0{ }^{14} \mathrm{C}$ age calibration program. $R a$ diocarbon 35(1):215-30.

Sulerzhitsky LD. 1997. Cherty radiouglerodnoi khronologii mamontov Sibiri i severa Vostochnoi Evropy (kak substrata dlya rasseleniya cheloveka) [The features of radiocarbon chronology of mammoths in Siberia and northern Eastern Europe (as substratum for human dispersal)]. In: Velichko AA, Soffer O, editors. Chelovek Zaselyaet Planetu Zemlya. Moscow: Institute of Geography, Russian Academy of Sciences. p 184-202. In Russian.

Sulerzhitsky LD. 2004. The chronological span of some Late Palaeolithic sites according to the radiocarbon dating of the bones of megafauna. Rossiiskaya Arkheologiya 3:103-12. In Russian with English abstract.

Sulerzhitsky LD, Pettitt P, Bader NO. 2000. Radiocarbon dates of the remains from the settlement Sunghir. In: Alekseeva TI, Bader NO, editors. Homo sungirensis. Upper Palaeolithic Man: Ecological and Evolutionary Aspects of the Investigation. Moscow: Nauchny Mir Publishers. p 30-4. In Russian with English abstract.

Taylor RE, Southon J. 2012. On the resolution of ${ }^{14} \mathrm{C}$ dating anomalies: case studies from New World archaeology. Radiocarbon 54(3-4):979-91.

Velichko AA, Faustova MA, Pisareva VV, Gribchenko YN, Sudakova NG, Lavrentiev NV. 2011. Glaciations of the East European Plain: distribution and chronology. In: Ehlers J, Gibbard PL, Hughes PD, editors. Quaternary Glaciations - Extent and Chronology: A Closer Look. Amsterdam: Elsevier. p 337-59.

Vogel J, Waterbolk HT. 1972. Groningen radiocarbon dates X. Radiocarbon 14(1):6-110.

Zenin VN, van der Plicht J, Orlova LA, Kuzmin YV. 2000. AMS ${ }^{14} \mathrm{C}$ chronology of woolly mammoth (Mammuthus primigenius Blum.) remains from the Shestakovo Upper Paleolithic site, Western Siberia: timing of human-mammoth interaction. Nuclear Instruments and Methods in Physics Research B 172(1-4):745-50. 